\title{
The Role of Human Resource Management Towards Employees Retention During Covid-19 Pandemic in Medical Supplies Sector - Egypt
}

\author{
Ashraf Elsafty ${ }^{1}$, Mohammad Ragheb ${ }^{2}$ \\ ${ }^{1}$ DBA., MBA., BSc., Adjunct Assistant Professor, ESLSCA Business School - Egypt Branch, Egypt \\ ${ }^{2}$ MBA, Bsc., Egypt Care for Supplies, Founder and CEO, Cairo, Egypt \\ Correspondence: Ashraf Saeed Elsafty, ${ }^{1}$ DBA., MBA., BSc., Adjunct Assistant Professor, ESLSCA Business School - \\ Egypt Branch, Egypt. E-mail: ashraf@ashrafelsafty.com
}

Received: June 10, 2020

doi:10.11114/bms.v6i2.4899
Accepted: July 28, 2020

Online Published: June 29, 2020

URL: https://doi.org/10.11114/bms.v6i2.4899

\begin{abstract}
The introduction of the report has mentioned the aim of this research. As per the introductory part, the aim of this research paper is to examine the role of Human Resources Management (HRM) towards the employees as far as curbing the adverse impact of Covid-19 is concerned. The Literature Review has mentioned the theories of motivation that impacts on the retention level of the employees, along with the studies conducted in the same domain. Some of the studies have been included in which strategies of the companies have mentioned to curb the negative impacts of Covid-19. The quantitative method has been utilized for the same research in which a total of 140 respondents have been selected on the scale of non-probability sampling. Descriptive Statistics and Correlation are the statistical metrics used for the same purpose. From the analysis, it is found that HR managers should play their role in maximizing the satisfaction level of their employees, and the major elements are mentioned in the analysis part. Workplace Guidelines \& Support and Access to Information and Financial benefits are some of the main elements that should have been considered by the entities for maximizing their income potential and values accordingly.
\end{abstract}

Keywords: employee retention, human resources, health care, medical supplies

\section{Introduction}

The recent Covid-19 has started from the city of Wuhan, China and engulfed the entire world into its fatal claws. The number of open cases and deaths has increased heavily since March 2020. Mentioned below at figure 1, two graphs are showing the open cases and deaths due to the recent Pandemic of 2020
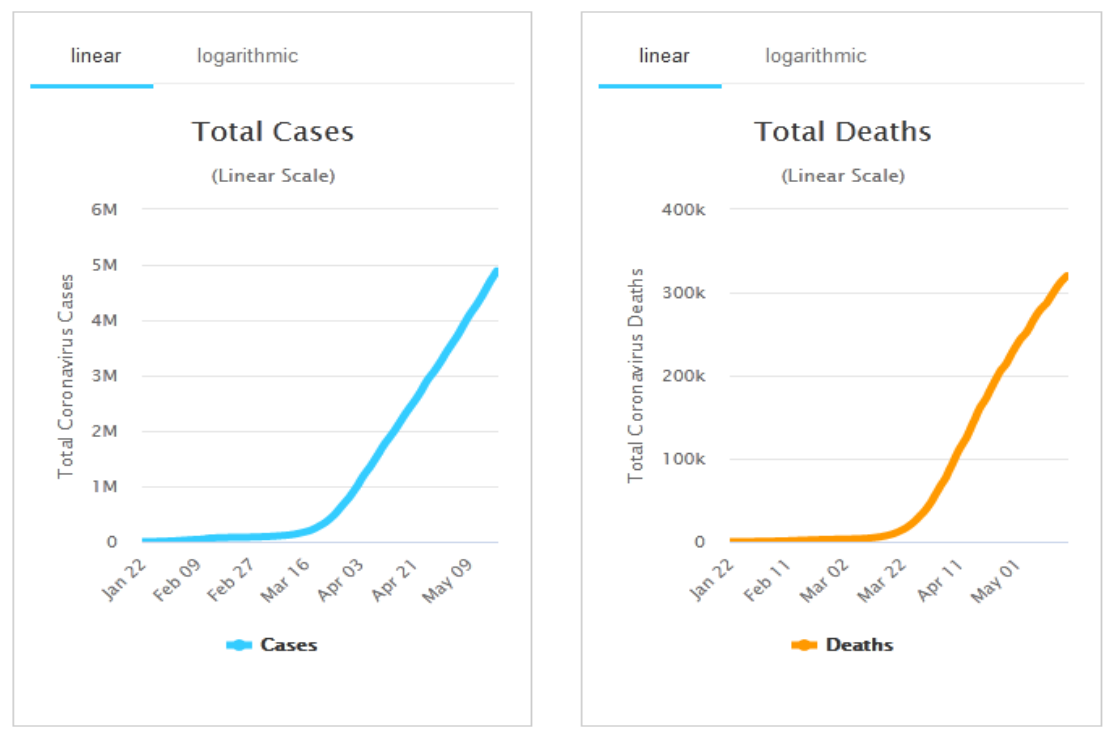

Figure 1. Open cases and deaths due to the recent Pandemic of 2020 
It is obvious that the number of open cases has now reached a level of 5 Million in all over the world. Likewise, the total cases, the number of deaths from Covid-19 is also increasing on per day basis. According to the World Health Organization (WHO), lockdown and restricting the people from Socializing is the only way to overcome the challenge.

The recent Pandemic in the form of Covid-19 has created a lot of mess all over the world. After engulfing a lot of lives across the globe, the recent Pandemic has left a lot of adverse impact on the economic well-being of the economies that include slashes of jobs or reducing their salaries. The impact of this factor varies from countries to countries. It means that its impact is adverse on some economies and lighter on the other. Nevertheless, most of the economies are having a tough economic time.

According to Elsafty (2018) (2019) analyzing contextual problem for research purposes, a proposed model called a 9-element model to analyze and define business anatomical models in business element research work. The model is clearly presented online (Elsafty, DrAshrafElsafty Channel, 2020), and the two published papers used the 9-element model (Elsafty, Elsayed and Shaaban, Egyptian student technical education). For proper and effective research, you need to consider 9 factors that determine the business structure of your context to be included in this business analysis and review. 9 elements to help you understand and integrate all functions of business and management (Elsafty, Business Research Methodology, 2019), which is used to analyze and present the context and the introduction for the current research.

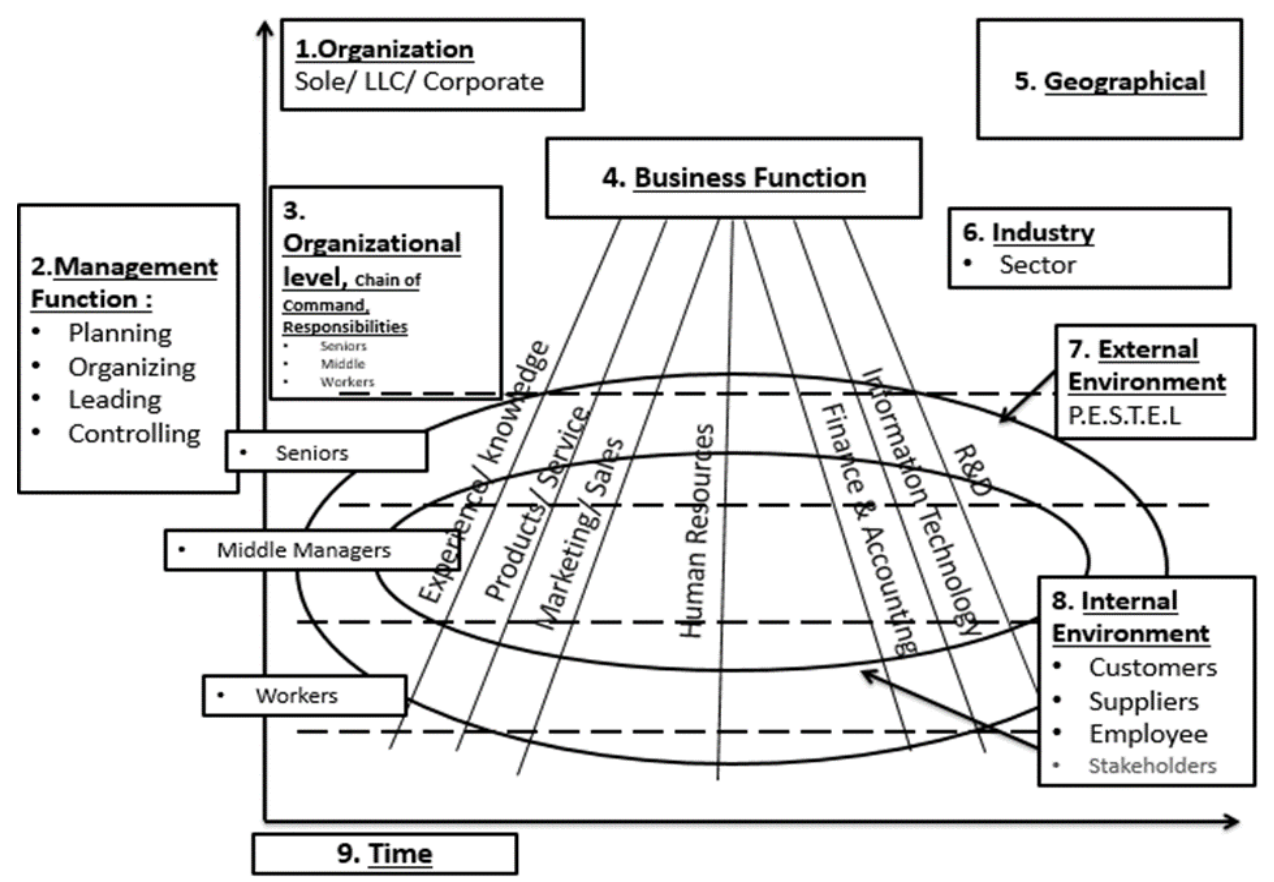

Figure 2. Business Anatomy: The 9 Elements Model Proposed by Elsafty (2018)

Due to losing of jobs abruptly and mounting the debt pressure, lots of employees across the globe are getting unsatisfied. The Human Resources (HR) department in different parts of the world, and in Egypt, is focusing on the retention of their employees professionally. For that purpose, they are taking a lot of measures and points into consideration.

This aim of this research paper is to examine the role of Human Resources Management (HRM) towards the employees as far as curbing the adverse impact of Covid-19 is concerned. The HR department is likely to retain the employees during the Covid-19 Pandemic.

Especially during pandemics, employees are a strategic asset of any organization, that has to be managed, preserved and retained, with focus on experienced and skilled ones. When they feel dissatisfied with the current job because of lack of several variables.

Consequently, organizations lose their invested resources for competitors, employees organizational relationship are then damaged and more over the moral goes down dramatically, which leads directly to low level of retention. 
Using the 9 elements model (Elsafty, 2018), and conducting stakeholders' analysis, through meeting with employees and decision makers, several variables raised comparing retention before pandemic versus during pandemic like covid-19, those variables related to periods before covid-19 could be listed as follows :

- Training and development.

- Compensation plans.

- Career plans.

- Organizational culture.

While retention variables are totally different during pandemic, the current case of covid-19, with major focus on the following variables as per contextual analysis:

- Missing enough information of the management plan and reaction responding to pandemic situation.

- Not enough clear guidelines, on what to do and what to avoid while in workplace.

- No clear or eve sudden information on financials during pandemic.

- No clear support of employee health outside the company premises.

- Lack of communication on pandemic from company official sources.

Therefore, the major objectives of the research comprise of the below-mentioned below:

- To explore the variables influencing the HR department to sustain good level of employee retention.

- To recommend possible steps or strategies that could be used by the HR department to sustain employees' retention during Covid-19

- To propose the focused role of the HRM for retaining their employees during Pandemic in general

The significance and value of this research is broad because it links with two different aspects at the same time. In one hand the research will be helpful for the HR department of different companies managing and retaining employees during turbulent and critical times, like pandemic covid-19. While in other hand, the research would be effective base for future researchers on pandemics related HR practices and studies.

\section{Literature Review}

Employees are the backbone of an entity and their existence is more than essential for them. Retention of the employees is a broad topic, and lots of companies look serious in this provision to maintain a healthy output with their employees (Bisht, Chaubey \& Thapliyal, 2016). The retention of the employees is associated directly with the policies made and implemented by the HR Department of a company. It is mandatory for an organization to provide their every employee the mean to satisfy their needs professionally and ethically. According to Al-sharafi, Hassan \& Alam (2018), the retention of the employees increases with their motivation. Motivation is then divided into two different factors which are intrinsic factors and extrinsic factors. Both of these factors of motivation are essential in generating lots of effectiveness and enhance their provision accordingly. According to Dhanya \& Prashath (2019), motivation is a driving force that enables an employee to become reactive, efficient and productive. High motivation of the employees could maximize the potential and satisfaction level of the employees that ultimately increases the values and productivity of the companies in particular.

There are certain factors that increase the motivation level of the employees proactively. These factors have been divided into two main types which are intrinsic motivation and extrinsic motivation. Both, intrinsic and extrinsic motivational factors are valuable in providing maximum satisfaction to the employees. Theoretically, as defined by Kuvaas, Buch, Weibel, Dysvik \& Nerstad (2017), intrinsic motivational factors are non-monetary factors that could increase the level of satisfaction among the employees, while the extrinsic motivational factors are monetary factors that increase the level of satisfaction in the employees. Some of the main examples of extrinsic motivation are bonuses, perks and competitive salaries. The motivational factors tend to change among the companies as per the requirements. Both of these methods are efficient as well as productive that ultimately value the organizations and enhance the productivity level of the employees. Therefore, each of these factors should have been considered as proactive for the value creation in particular. Bear, Slaughter, Mantz \& Farley-Ripple (2017) identified the role of the HRM towards their employees during Medical-Based Pandemics and the Financial Slumps. Some of the main factors that define by the author are as follows

- Workplace Guideline and Support

- Access to Information and Updates on Pandemic with Financial Benefits

- Health Related Quality of Life

- Communication and Promoting Message

These four factors have been taken into consideration in this research as well. As per the views shared by Eliza Wong \& Kin (2020), Workplace Guideline and Support during a hard time are always a sigh of relief that helps the employees to 
regain their confidence and motivation. It increases the level of motivation of the employees and satisfies their needs accordingly. Access to Information and Updates on Pandemic with Financial Benefits is the most suitable and effective benefits that provide by the entities to their end-users. Especially, during the hard times such as Pandemic, an organization should not get away in providing provisional healthcare benefits to its employees, as it is one of the most important retention techniques available to them. As per the opinion shared by Khoshnevin \& Gholipoui (2017), there are companies that give certain bonuses to their employees during hard times in order to tackle the situation. The same factor is applicable in the context of this research as well in which analysis of the Pandemic Bonuses have been discussed accordingly. It is also observed from the previous analysis that companies cut the salaries of the employees during their hard times that made them fully unsatisfied with the policies of the entity and ultimately increases employees' turnover. There was a research conducted in the same domain, and it was initiated by Khalil \& Hashim (2019). The researcher identified the importance and implication of different motivational factors that use for retaining the employees for a long span of time.

The researcher used both, monetary and non-monetary benefits into the account and frequency distribution has taken into consideration. The researcher managed to find a significant connection between motivational outputs and its satisfaction of the employees accordingly. There was a research conducted and presented by Kuvaas et al., (2017). The research was conducted in the region of the United Kingdom (UK), in which the importance of intrinsic and extrinsic motivation has been visualized. The research was conducted through the quantitative method in which primary data collection method has been used. The data collection was through the close-ended questionnaire in which descriptive statistics and linear regression has been applied. Based on the applicable statistical metrics, it is found that the connection between intrinsic/extrinsic motivations are high and positive with satisfaction of the employees that ultimately assist them in retaining them for a certain time period. The research also idealized that both of these motivational factors are productive in the hard economic times, such as the current time.

\section{Methodology}

The most important thing that found in a research report is related to its method. The most powerful method of research, the most valuable would be the outcome. There are several factors that directly and indirectly impact on the same provision. The foremost one is the Research Design. As per the theory, the design considers by a researcher for the purpose of data evaluation and analysis is referred to as Research Design (Sekara \& Bougie, 2016). It is often divided into different types that include Descriptive, Longitudinal and others. This particular research is using "Descriptive in Design", in which the variables related to Pandemic have been evaluated. Another important factor that has been evaluated in the same output is Research Methods. It is the methods which are effective in applying for assimilating the desired dataset. The research method that has been considered in this analysis is "Quantitative" in which quantification has been considered on the collected data. The main rationale in using this research method is clear, as proper quantification is helpful in taking the most valuable outcome and result at the end of the day. Data Collection tool that has been considered here is Primary in which a questionnaire is used for the data collection purpose. The questionnaire is mentioned in the Appendix of the report that has been collected through Eliza \& Kin (2020). The variables used in that research were more, however due to the space issue we have restricted to use four.

Sampling is another important thing that connects with the research method and data collection method directly. Sampling is the total amount of respondents included in the analysis. Questionnaire targeting the employee in health care industry, with focus on medical supplies sector, which is estimated as a population of 12,000 employees (CAPMAS, 2019). The questionnaire sent to a database of 1,000 employees, as a sufficient sample representation using www.Raosoft.com/samplesizecalculator using confidence level of $97 \%$ and Error level of 7\%. The response rate of the targeted 1000 reached 140, which is considered high within Egyptian culture response rate as $14 \%$. The sample size that has been used in the same assessment is 140. It means that 140 respondents have been selected for the purpose of data collection. The statistical tools that have been covered in the same outcome are Descriptive Statistics and Correlation (Kumar et al., 2017).

\subsection{Hypothesis and Theoretical Framework}

$\mathrm{H} 1_{0}$ : No significant relationship is found between Workplace Guideline and Support during Pandemic of Covid-19 and Retention of Employees

$\mathrm{H} 1_{\mathrm{a}}$ : A significant relationship is found between Workplace Guideline and Support during Pandemic of Covid-19 and Retention of Employees

$\mathrm{H} 2_{0}$ : No significant relationship is found between Access to Information on Pandemic with Financial Benefits and Retention of Employees

$\mathrm{H} 2_{\mathrm{a}}$ : A significant relationship is found between Access to Information on Pandemic with Financial Benefits and 


\section{Retention of Employees}

$\mathrm{H} 3_{0}$ : No significant relationship is found between Health Related \& Quality of Life and Retention of Employees

$\mathrm{H}_{\mathrm{a}}$ : A significant relationship is found between Health Related \& Quality of Life and Retention of Employees

$\mathrm{H} 4_{0}$ : No significant relationship is found between Communicating \& Promoting Message during Pandemic of Covid-19 and Retention of Employees

$\mathrm{H}_{\mathrm{a}}$ : A significant relationship is found between Communicating \& Promoting Message during Pandemic of Covid-19 and Retention of Employees

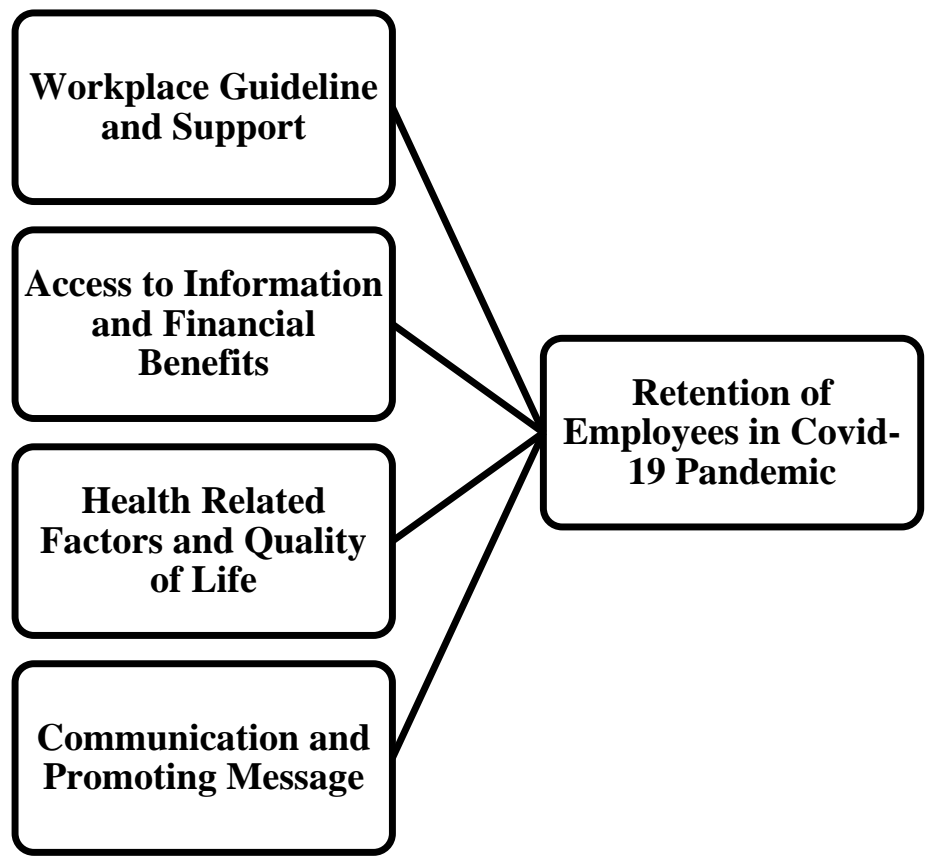

Figure 3. Research Theoretical Framework

\section{Data Analysis}

The current Pandemic is having an adverse but definite impact on the economic prosperity of the companies across the globe. Some of the initial questions have been analyzed through the Frequency Distribution. The general questions were about the current Pandemic of Covid-19 and its impact on the economy and workplaces in particular. The foremost question is about to explore the current Pandemic of Covid-19 and its adverse impact on the economy. It means that the question was to get the input of the individuals about the intensity of the current Pandemic.

It is clearly found from the analysis that most of the individuals were agreed with the fact that the current Pandemic of Covid-19 is having a tough impact on the overall economy of the world. Around $29 \%$ of the total respondents were Strongly Agreed with the fact that the Pandemic of Covid-19 is producing different issues and problems for the entire economy, which is indeed a major problem for the economies particularly. Apart from the economy, the current Pandemic seems totally devastating for the workplaces, and the output of the same question is mentioned in the analysis. From the analysis, it is found that most of the respondents were Strongly Agreed (41\%) with the fact that workplaces were affected heavily and adversely during the recent Pandemic of Covid-19, while $29 \%$ of them were Agreed. $17 \%$ and $10 \%$ were disagreed and Strongly Disagreed with the same outcome respectively. Most of these respondents clearly identified that the recent Pandemic increased the Job layoffs problems across the world.

\subsection{Descriptive Statistics}

It is indeed a valuable and widely used statistical metric that summarizes the data professionally. The descriptive output and mean plots are as follows 
Table 1. Concluded Descriptive Statistics

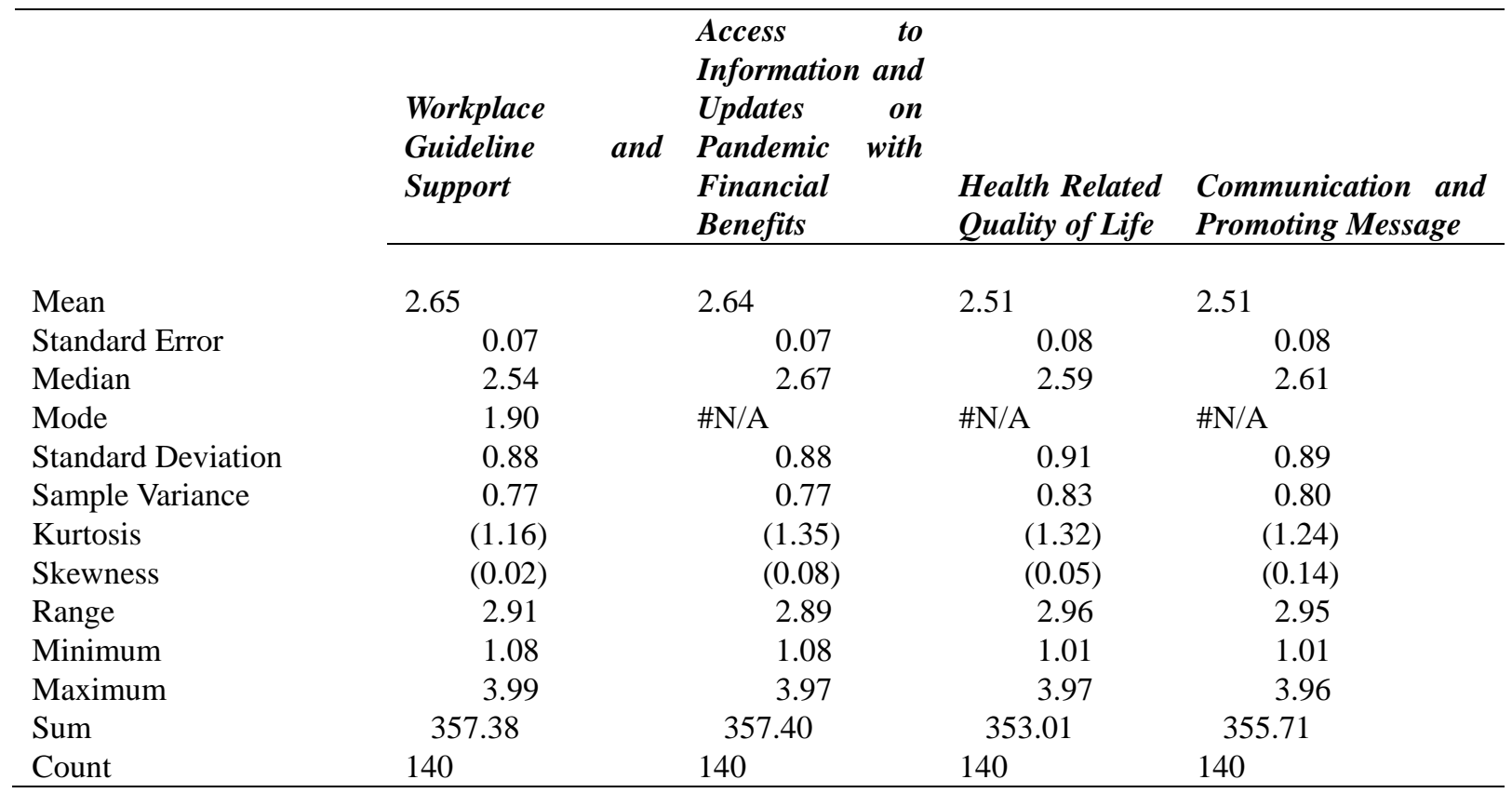

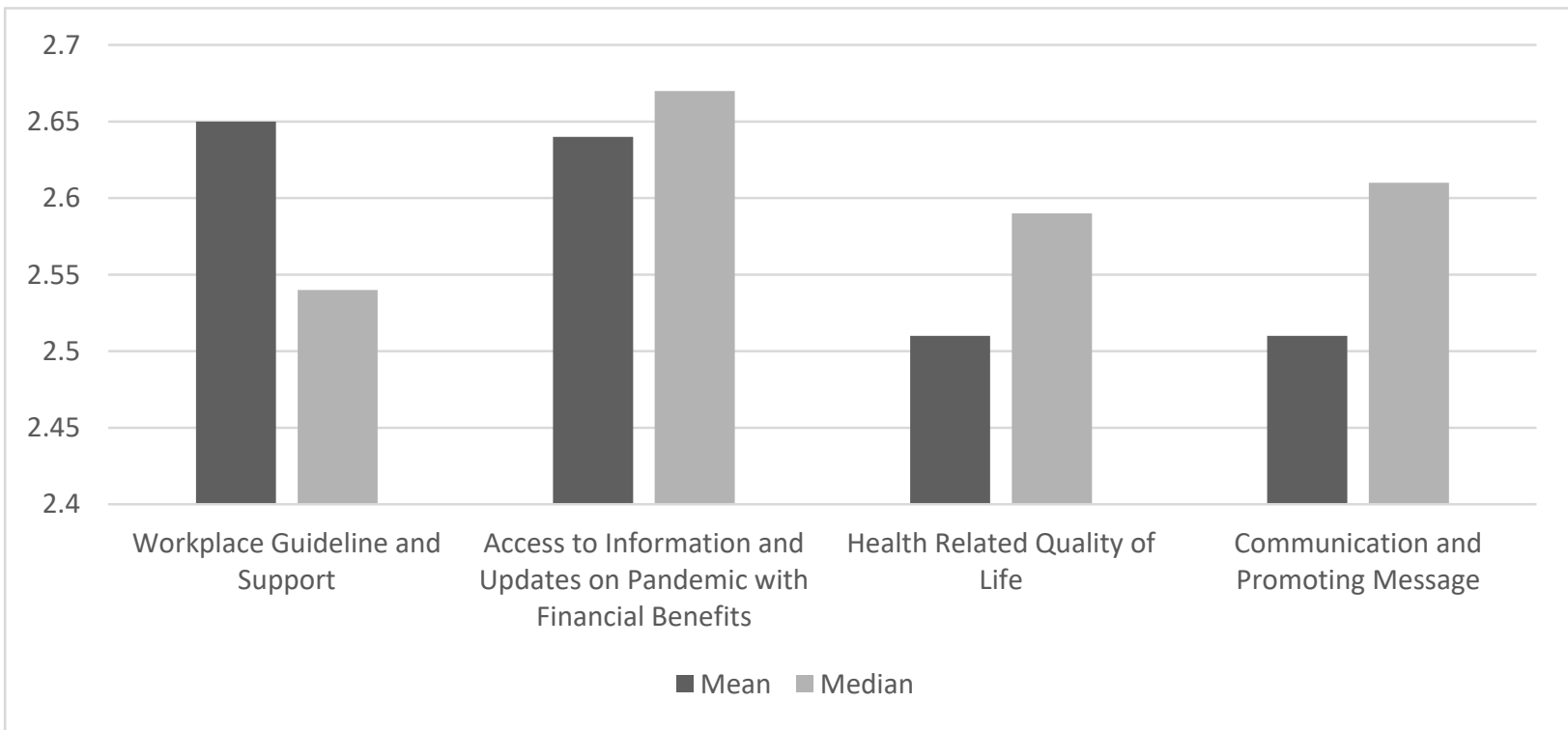

Figure 4. Variables Descriptive Comparison

The first column is showing the importance of Workplace Guideline and Support with the incremental satisfaction of the employees as well as their retention level. The mean value against the same output is " 2.65 " that tilt more towards" 3 ". The median value is also relating the same, which is showing a value of " 2.54 ". It means that most of the respondents were "Agreed" with the fact that the HRM should play an important role in providing Workplace Guideline and Support to their employees as it increases the level of retention of the employees during the Pandemic of Covid-19.

The $2^{\text {nd }}$ and $3^{\text {rd }}$ columns are showing the Access to Information and Updates on Pandemic with Financial Benefits/Health Related Quality of Life and their significance in terms of increasing the Employees' retention and satisfaction. The mean values found in the chart against the same output are "2.64" and "2.51" that tilt more towards"3".

The median values against these factors are also favorable, showing a value of 2.67 and 2.59 respectively. It means that most of the respondents were "Agreed" with the fact that the HRM of the entities need to provide Access and Update on Pandemic and Financial Benefits, so that they can be retained with them for a long span of time, especially during the Covid-19 Pandemic. Last, but not the least, there is another element with the narration of Communication and Promoting Message. The mean value against the same element is "2.51", shows that respondents were agreed with that 
Communication and Promoting Message should be provided by the entities to their employees so that they can be retained accordingly.

\subsection{Correlational/Inferential Analysis}

Correlation is yet another important tool that assesses the relationship (if any) between the dependent and independent variables. The correlation is as follows

Table 2. Concluded Correlation Matrix

\begin{tabular}{|c|c|c|c|c|c|}
\hline & $\begin{array}{l}\text { Employees } \\
\text { Retention }\end{array}$ & $\begin{array}{l}\text { Workplac } \\
\text { e } \\
\text { Guideline } \\
\text { and } \\
\text { Support }\end{array}$ & $\begin{array}{l}\text { Access to } \\
\text { Informatio } \\
\text { n and } \\
\text { Updates on } \\
\text { Pandemic } \\
\text { with } \\
\text { Financial } \\
\text { Benefits } \\
\end{array}$ & $\begin{array}{l}\text { Health } \\
\text { Related } \\
\text { Quality } \\
\text { of Life }\end{array}$ & $\begin{array}{l}\text { Communicatio } \\
\text { n and } \\
\text { Promoting } \\
\text { Message }\end{array}$ \\
\hline Employees' Retention & 1 & & & & \\
\hline Workplace Guideline and Support & 0.41246 & 1 & & & \\
\hline $\begin{array}{l}\text { Access to Information and Updates on } \\
\text { Pandemic with Financial Benefits }\end{array}$ & 0.51124 & 0.062678 & 1 & & \\
\hline Health Related Quality of Life & 0.658114 & -0.07791 & $\mathbf{0 . 0 3 7 7 2 5}$ & 1 & \\
\hline Communication and Promoting Message & 0.35221 & 0.049527 & 0.031155 & $\begin{array}{l}0.11032 \\
6\end{array}$ & 1 \\
\hline
\end{tabular}

From the aforementioned table 2, it is found that the variables have a positive connection with each other in order to overcome the adverse impact of Covid-19. Workplace Guideline and Support is an important measure that increases the employee's retention. The Pearson Correlation Factor that connects with the same assessment is " 0.41 ", which is not high and lower average that means the connection between such variables is somewhat insignificant. Apart from that Access to Information and Updates on pandemic with Financial Benefits and Pandemic Bonus and Quality of Life are some other elements that have a strong connection with the Employees' retention. The Pearson Correlation against both of these elements is "0.51" and "0.65", which means that the higher the provision of these benefits during the Pandemic of Covid-19, the higher would be the retention of the employees. Lastly, full compensation and appreciation are some other tools that could be used by the HR managers to increase the level of satisfaction as well as the retention of the employees. The correlation factor is low manifesting a value of " 0.35 ". It is locating on a lower scale, which is enough to identify that the connection between compensation/appreciation with employee's retention on Pandemic is insignificant.

According to hypothesis tested, the analysis supported $\mathrm{H} 2_{\mathrm{a}}$ and $\mathrm{H} 3_{\mathrm{a}}$, while could not support fully $\mathrm{H} 1_{\mathrm{a}}$ and $\mathrm{H} 4_{\mathrm{a}}$. Accordingly, the research identified that Health Related Quality of Life is the most important variable related to retention, followed by Access to Information and Updates on Pandemic with Financial Benefits, therefore providing bonuses at the right and tough time is valuable to maximize the retention level of the employees and suppress them to become more effective for the entity in particular.

\section{Discussion and Conclusion}

There was a total of two different objectives that included in the same assessment. The first one is about exploring the strategies used by the HR department to overcome major issues of the employees during Covid-19. From the analysis, it is found that there are certain strategies that could be used by the management to overcome the employees' issues, specifically during the Pandemics. The research demonstrated that Access of Information and updates on Pandemic and Financial Benefits are the most valuable factors that increase the retention level of the employees. In terms of the current issues of Covid-19 Pandemic, most of the respondents identified it as major economic problems in all over the world due to which job layoffs increased and most of the individuals have claimed for the employment benefits from the Government. This particular aspect has been second by Sarmad et al., (2017). According to the researcher, particularly in the United States, Millions of People went unemployed during the recent Pandemic of Covid-19. This particular outcome is the same as presented by Walker Accadia, R., \& Costa (2016) in their research. 
There is another research that was conducted by Wassem et al., (2019), as per the researcher, apart from the extrinsic rewards, there are intrinsic rewards as well which are essential for the HR managers to increase the level of satisfaction in the employees that ultimately increases their retention. The researcher idealized that communicating with the employees from the management and informs them about the Pandemic and intensity could be ideal for the employees to get satisfied and retain with the company accordingly. This outcome will be effective for the companies, in the current time period as well, and in all over the world because the effect of Covid-19 is currently spreading in every single economy of the world. Based on the same analysis, it is recommended to the HR managers to play their role with diligence and dedication, so that the employees can be retained for a long span of time. The respondents also identified that Serious and Timely Actions should have been taken by the Government to overcome the issues.

Quaedackers et al., (2020) also revealed the same thing, as according to them, employees' friendly strategies should have been used by the Government and Workplaces to reduce the negative impact of this Pandemic of Covid-19, and make the employees more satisfied and productive. Some of the major organizations that impacted heavily during the recent Pandemic are Airline, Automobiles and Oil and Gas sector. Millions of people across the globe are directly and indirectly linking with the same industry, who are unemployed. Therefore, it is up to the Government that which of the tactics that should have been used by them to overcome the major issues and problems.

The recommendations based on the correlation analysis is as follows

- Health Related \& Quality of Life and Access to information and updates on the Pandemic with Financial benefits, are the most important variables to the retention of employees, and should have been provided appropriately to the employees so that they can be retained.

- It is imperative and valuable for the companies to inform the Workplace Guidelines and Support to the employees, especially at the time of Pandemic such as Covid-19.

- Proper Communication should have been done with them, so that they can inform the management about the problems which they are facing, especially in the Pandemic time.

For future research implication, it is suggested to use a mixed methodology, in which interviews of the professional individuals should have been taken and ask them about their strategies used for overcoming the Pandemic crisis.

\section{References}

Al-sharafi, H., Hassan, M. E. M., \& Alam, S. S. (2018). The Effect of Training and Career Development on Employees Retention â€"A Study on the Telecommunication Organizations in Yemen. The Journal of Social Sciences Research, 420-430. https://doi.org/10.32861/jssr.spi2.420.430

Bear, G. G., Slaughter, J. C., Mantz, L. S., \& Farley-Ripple, E. (2017). Rewards, praise, and punitive consequences: Relations with intrinsic and extrinsic motivation. Teaching and Teacher Education. https://doi.org/10.1016/j.tate.2017.03.001

Bibi, P., Ahmad, A., \& Majid, A. H. A. (2018). The impact of training and development and supervisor support on employees retention in academic institutions: The moderating role of work environment. Gadjah Mada International Journal of Business, 20(1), 113. https://doi.org/10.22146/gamaijb.24020

Bisht, S., Chaubey, D. S., \& Thapliyal, S. P. (2016). Analytical Study of Psychological Contract and its Impact on Employees Retention. Pacific Business Review International, 8(11).

Dhanya, M. R., \& Prashath, R. T. (2019). A Study on Drivers of Employee Engagement and Employee Retention in Healthcare Sector, Tiruchirappali Corporation. Journal of the Gujarat Research Society, 21(7), 222-233.

Eliza, L Wong \& Kin, F. (2020), Workplace safety and coronavirus disease (COVID-19) pandemic: survey of employees. Public Health and Care Facility, 12(2). https://doi.org/10.2471/BLT.20.255893

Elsafty, A. (2019). Business research methodologies. Assiut, Egypt: Eslsca Business school.

Elsafty, A. (2020, 1 21). DrAshrafElsafty Channel. Retrieved from Youtube: https://www.youtube.com/watch?v=y-jDT2iOOhU\&list=PLKSWZdnzp8p3uFLLh2N8_d0W7ZmJDLMjW\&index $=42 \& \mathrm{t}=628 \mathrm{~s}$

Elsafty, A., El Sayad, H., \& Shaaban, I. (2020, May). A Business Analysis Perspective for Engineering Education in Egypt. Journal of Education and Training Studies. https://doi.org/10.11114/jets.v8i5.4721

Elsafty, A., Elsayed, H., \& Shaaban, I. (2020). Educating Engineering Students in Egypt: Recommendations for Improvement. International Journal of Higher Education. https://doi.org/10.5430/ijhe.v9n3p1

Johennesse, L. A. C., \& Chou, T. K. (2017). Employee Perceptions of Talent Management Effectiveness on Retention. 
Global Business \& Management Research, 9(3).

Khalil, M. A. K. B. M., \& Hashim, R. A. (2019, April). MEDIATING EFFECTS OF GENERATION Y WORK VALUES'IN HUMAN RESOURCE PRACTICES AND EMPLOYEE RETENTION IN MALAYSIA. In ICE 2019 CONFERENCE PROCEEDINGS (p. 213).

Khoshnevis, M., \& Gholipour, A. (2017). Exploring the Relationship Between Employer Brand and Employees' Retention. International Journal of Scientific \& Engeneering research, 8(10), 141-151.

Kuvaas, B., Buch, R., Weibel, A., Dysvik, A., \& Nerstad, C. G. (2017). Do intrinsic and extrinsic motivation relate differently to employee outcomes?. Journal of Economic Psychology, 61, 244-258. https://doi.org/10.1016/j.joep.2017.05.004

Quaedackers, J. S., Stein, R., Bhatt, N., Dogan, H. S., Hoen, L., Nijman, R. J., ... \& Bogaert, G. (2020). Clinical and surgical consequences of the COVID-19 pandemic for patients with pediatric urological problems. Statement of the EAU guidelines panel for pediatric urology, March 30 2020. 2020. Journal of Pediatric Urology. https://doi.org/10.1016/j.jpurol.2020.04.007

Sarmad, M., Ajmal, M. M., Shamim, M., Saleh, M., \& Malik, A. (2016). Motivation and Compensation as Predictors of Employees' Retention: Evidence From Public Sector Oil and Gas Selling Organizations. Journal of Behavioural Sciences, 26(2).

Sekaran, U., \& Bougie, R. (2016). Research methods for business: A skill building approach. John Wiley \& Sons.

Walker, A., Accadia, R., \& Costa, B. M. (2016). Volunteer retention: The importance of organisational support and psychological contract breach. Journal of community psychology, 44(8), 1059-1069. https://doi.org/10.1002/jcop.21827

Wassem, M., Baig, S. A., Abrar, M., Hashim, M., Zia-Ur-Rehman, M., Awan, U., ... \& Nawab, Y. (2019). Impact of Capacity Building and Managerial Support on Employees' Performance: The Moderating Role of Employees' Retention. SAGE Open, 9(3), 2158244019859957. https://doi.org/10.1177/2158244019859957

\section{Appendix-Questionnaire}

\section{SECTION A: Demographic Information:}

Name of the Bank of which you are using the Credit Card.

Gender.

Age.

\begin{tabular}{|l|l|l|l|}
\hline $18-25$ & $26-35$ & $36-40$ & $40+$ \\
\hline & & & \\
\hline
\end{tabular}

Marital Status.

\begin{tabular}{|l|l|l|l|}
\hline Single & Married & Divorced & Widow \\
\hline & & & \\
\hline
\end{tabular}

Name of the Organization where you are employed/studying?

Education.

\begin{tabular}{|l|l|l|}
\hline Master & Bachelor & Intermediate \\
\hline & & \\
\hline
\end{tabular}


SECTION B: Human Resources Roles to Retain the Employees in Covid-19 Pandemic:

\begin{tabular}{|c|c|c|c|c|c|}
\hline & $\begin{array}{l}\text { Strongly } \\
\text { Agree }\end{array}$ & Agree & Neutral & Disagree & $\begin{array}{l}\text { Strongly } \\
\text { Disagree }\end{array}$ \\
\hline \multicolumn{6}{|l|}{$\begin{array}{l}\text { The Current Pandemic of Covid-19 brought adverse } \\
\text { impact on the overall economy }\end{array}$} \\
\hline \multicolumn{6}{|l|}{$\begin{array}{l}\text { Covid-19 seems highly ineffective for the workplaces in } \\
\text { all over the world }\end{array}$} \\
\hline \multicolumn{6}{|l|}{$\begin{array}{l}\text { The current Pandemic of Covid-19 have increased Job } \\
\text { Layoffs across the World }\end{array}$} \\
\hline \multicolumn{6}{|l|}{$\begin{array}{l}\text { Their roles can increase the satisfaction level among the } \\
\text { employees }\end{array}$} \\
\hline \multicolumn{6}{|l|}{$\begin{array}{l}\text { Workplace Guideline and Support can increase the } \\
\text { retention level of Employees in Covid-19 Pandemic }\end{array}$} \\
\hline \multicolumn{6}{|l|}{$\begin{array}{l}\text { Access to Information and Updates on Pandemic can } \\
\text { increase the retention level of Employees in Covid-19 } \\
\text { Pandemic }\end{array}$} \\
\hline \multicolumn{6}{|l|}{$\begin{array}{l}\text { Providence of Financial Benefits can increase the } \\
\text { retention level of Employees in Covid-19 Pandemic }\end{array}$} \\
\hline \multicolumn{6}{|l|}{$\begin{array}{l}\text { Health Related Factor and Quality of Life can increase } \\
\text { the retention level of Employees in Covid-19 Pandemic }\end{array}$} \\
\hline $\begin{array}{l}\text { Communication and Promoting Message in overcoming } \\
\text { the current issues and problems of Pandemic of Covid-19 }\end{array}$ & & & & & \\
\hline
\end{tabular}

\section{Copyrights}

Copyright for this article is retained by the author(s), with first publication rights granted to the journal.

This is an open-access article distributed under the terms and conditions of the Creative Commons Attribution license which permits unrestricted use, distribution, and reproduction in any medium, provided the original work is properly cited. 